\title{
ANALISIS RESPON SISWA SMA PLUS AL - AZHAR JEMBER TERHADAP MODUL FISIKA DIGITAL BERBASIS ARTICULATE STORYLINE 3 POKOK BAHASAN HUKUM NEWTON TENTANG GRAVITASI
}

\author{
${ }^{1)}$ Jihan Ni'ami Midroro, ${ }^{1)}$ Sri Handono Budi Prastowo, ${ }^{1)}$ Lailatul Nuraini \\ ${ }^{1)}$ Program Studi Pendidikan Fisika FKIP Universitas Jember \\ Email: 170210102080@ students.unej.ac.id
}

\begin{abstract}
The Covid-19 pandemic has an impact on many things, one of which is education. Changes that occur in the field of education are a learning system that is used as a distance learning system. Physics is a subject that is considered less attractive and tends to be boring. One of the reasons physics is considered boring is the lack of learning media to support physics material, especially digital ones. The purpose of this study was to analyze the responses of Al-Azhar Jember Senior High School students after using physics learning media in the form of an interactive digital physics module based on Articulate Storyline3, the subject of Newton's law about gravity. This research method is a quantitative research method using an instrument in the form of a response questionnaire given to class X MIPA SMA Plus Al-Azhar Jember via the google form page. Based on the research that has been done, it shows that digital physics moul gets a very positive response from respondents. The digital physics module obtained a score of $81,60 \%$ on a limited scale trial and a score of $83.86 \%$ on a wide-scale trial.
\end{abstract}

Key word: digital module, physics learning, students response

\section{PENDAHULUAN}

Indonesia menjadi salah satu negara yang terdampak pandemi covid-19. Bidang pendidikan menjadi salah satu sektor yang harus beradaptasi agar mampu terus bergerak ditengah hambatan karena keterbatasan keadaan pandemic covid-19. Perubahan yang terjadi di bidang pendidikan adalah peralihan sistem pembelajaran tatap muka di sekolah menjadi sistem pembelajaran jarak jauh. Sistem pembelajaran online ini menekankan siswa untuk lebih berperan aktif. Pembelajaran jarak jauh selama wabah virus corona, masih menemui banyak kendala di lapangan sekalipun sudah ada edaran menteri agar proses belajar dari rumah dilaksanakan secara online atau daring. Sebagian siswa tidak dapat mengikuti pembelajaran secara online atau daring karena ketiadaan sinyal jaringan internet (Atsani, 2020: 88). Kendala ini menyebabkan tidak semua siswa dapat mengikuti tatap muka baik via zoom maupun google meet yang diberikan oleh guru atau pendidik.

Perkembangan teknologi dalam dunia pendidikan telah banyak menghasilkan inovasi baru yang bermanfaat untuk menunjang proses pembelajaran, salah satunya adalah semakin banyaknya variasi bahan ajar. (Jamun, 2018) mengemukakan bahwa dalam pendidikan teknologi memiliki pengaruh yang sangat kuat. Adanya teknologi menjadikan guru mampu mengkombinasikan teknologi dalam proses 
pemelajaran, seperti menciptakan berbagai media serta bahan ajar yang memanfaatkan teknologi. Pada proses pembelajaran yang didalamnya terdapat keterbatasan ruang, waktu, dan daya indera, media dapat berfungsi sebagai sebuah jembatan penghubung yang dapat menghilangkan keterbatasan tersebut. Seperti saat siswa perlu untuk mengamati sebuah objek yang terlalu besar ataupun terlalu kecil maka media gambar, film atau model dapat digunakan sebagai alternatif dari pengamatan secara langsung yang tidak memungkinkan. Begitu juga ketika perlu mengamati gerak benda yang terlalu cepat ataupun mengamati sebuah objek yang terlalu kompleks dapat menggunakan media yang tepat (Sadiman, 2007).

Salah satu bentuk media pembelajaran yang dapat digunakan secara mandiri oleh peserta didik adalah modul. Modul yang baik hendaknya mencakup secara keseluruhan meliputi gambaran kompetensi yang ingin dicapai, materi yang ditulis dengan bahasa yang baik dan menarik dilengkapi dengan ilustrasi atau contoh, dituliskan secara runtut supaya mudah dipahami, dilengkapi lembar kerja dan kunci jawaban (Prasetya, 2012: 108). Berdasarkan pemaparan di atas dapat disimpulkan bahwa modul yang baik serta dapat digunakan secara mandiri adalah modul yang bisa digunakan oleh siswa untuk melalui setiap proses pembelajaran.

Fisika menjadi salah satu mteri yang cukup abstrak dan perlu adanya praktikum atau pengamatan secara langsung. Salah satu materi fisika yang abstrak adalah materi hukum newton tentang gravitasi. Materi ini memaparkan tentang gaya tarik - menarik antara benda- benda yang ada di alam semesta. Jika tidak ada gaya tarik - menarik tersebut maka benda-benda di alam semesta (galaksi, bintang, planet, satelit, dan lainlain) akan bergerak tanpa terkontrol sehingga dapat menyebabkan saling menjauh atau saling bertumbukan. Hukum Kepler tentang gerak planet merupakan konsekuansi logis (implikasi) dari hukum Gravitasi Newton (Mikrajuddin, 2017: 1).

Pandemi covid-19 menyebabkan kegiatan praktikum tidak bisa dilaksanakan secara maksimal dan pengamatan secara langsung tidak dapat dilakukan. Hal ini menyebabkan siswa mengalami kendala dalam mempelajari materi fisika. Pemanfaatan teknologi dalam pembelajaran fisika di beberapa sekolah hanya terbatas pada penggunaan untuk keperluan zoom meeting maupun google meet saja. Salah satu sekolah yang terdampak pandemi ini dan masih mengalami kendala di bidang pemanfaatan teknologi untuk menunjang pembelajaran selama pandemic covid -19 adalah SMA Plus Al-Azhar Jember.

Berdasarkan hasil wawancara kepada guru mata pelajaran fisika di SMA Plus AlAzhar Jember menyatakan bahwa peserta didik cenderung bosan dan kurang tertarik untuk belajar fisika, salah satunya dikarenakan media pembelajaran yang digunakan sejauh ini masih monoton, kurang menarik, dan tidak praktis. Media pembelajaran yang dibutuhkan oleh siswa SMA Plus Al-Azhar Jember adalah media yang menarik dan praktis serta dapat digunakan oleh siswa untuk belajar secara mandiri, mengingat durasi tatap muka anatar guru dengan siswa dipangkas karena penyesuaian kurikum untuk pembelajaran selama daring.

Respon siswa merupakan salah satu faktor penting yang ikut menentukan keberhasilan belajar siswa. Kurangnya respon siswa terhadap pembelajaran akan menghambat proses pembelajaran. Respon positif siswa dapat dijadikan tolak ukur bahwa siswa merasa lebih nyaman dengan bahan ajar yang digunakan dalam proses pembelajaran. Sebagian besar perhatian siswa akan terfokus pada proses pembelajaran karena ketertarikan siswa 
terhadap bahan ajar dan siswa tidak akan cepat merasa bosan terhada pembelajaran (Nugraha et al., 2013).

Salah satu software media pembelajaran yang dinilai mampu untuk mengatasi problem yang dialami oleh siswa SMA Plus Al-Azhar Jember adalah software yang berbasis Articulate Storyline 3. (Purnama \& Asto, 2014) memaparkan bahawa Articulate Storyline 3 adalah perangkat lunak yang difungsikan sebagai media komunikasi atau presentasi. Media pembelajaran menggunakan software ini tidak kalah menarik dengan media interaktif lainnya. Penggunaan media ini diharapakan mendapat respon yang positif dari siswa sebagai penggunanya. (Sulardi et al., 2017)memaparkan bahwa Respon belajar siswa bermakna tentang pendapat atau tanggapan siswa terhadap pelaksanaan pembelajaran yang menggunakan suatu perangkat pembelajaran.

Berdasarkan pemaparan masalah, maka penelitian ini akan membahas tentang "Analisis Respon Siswa SMA Plus Al-Azhar Jember terhadap Modul Fisika Digital Berbasis Articulate Storyline 3 Pokok Bahasan Hukum Newton Tentang Gravitasi” dengan tujuan untuk mendeskripsikan respon siswa SMA Plus Al-Azhar Jember setelah melalui proses pembelajaran menggunakan modul fisika digital.

\section{METODE}

Penelitian ini menggunakan metode penelitian kuantitatif (Mulyadi, 2011) memaparkan bahwa metode penelitian kuantitatif merupakan metode untuk meneliti populasi atau sampel dengan menggunakan instrumen dalam mengumpulkan data. Instrumen yang digunakan dalam penelitian ini adalah berupa angket (respon) untuk responden melalui laman googleform. Hasil angket (respon) akan disajikan dalam bentuk tabel, grafik, atau diagram dan analisis dilakukan secara deskriptif (Mastuti, 2016).

Penelitian tentang respon siswa terhadap penggunaan modul fisika digital dilakukan pada mata pelajaran fisika kelas X MIPA semester ganjil tahun akademik 2020/2021. Penelitian ini dilakukan dengan mengujicobakan modul fisika digital yang berbasis Articulate Storyline 3 pada pokok bahasan hukum newton tentang gravitasi. Langkah yang dilakukan adalah memberikan modul fisika digital kepada guru pengajar kelas $\mathrm{X}$ MIPA SMA Plus Al-Azhar, kemudian membagi responden menjadi 2 kloter. Pada uji coba skala kecil terdiri dari responden sebanyak 6 orang siswa dan pada uji coba skala besar terdiri dari 19 orang siswa.

Setelah media selesai diuji cobakan kepada siswa, maka langkah yang dilakukan selanjutnya adalah mengumpulkan data berupa angket respon siswa mengenai pembelajaran fisika yang ditunjang dengan media berupa modul fisika digital interaktif berbasis Articulate Storyline 3 kepada 6 orang responden uji coba skala kecil. Angket respon terdiri dari 10 butir pernyataan yang mencakup 3 aspek yaitu tentang penyajian modul, kejelasan isi, dan ketercapaian tujuan. Selain itu juga terdapat kolom untuk mengisikan kesan dan pesan siswa terhadap modul fisika digital yang telah digunakan. Kemudian langkah yang sama juga dilakukan pada uji coba skala luas.

Teknik analisis deskriptif kuantitatif digunakan untuk mengolah data yang diperoleh melalui angket dalam bentuk deskriptif presentase. Persentase data dari angket respon siswa yang diperoleh dihitung berdasarkan skala Likert dengan keterangan sebagai berikut:

1) skor 4 mewakili pilihan "sangat setuju" pada pernyataan positif atau pilihan "sangat tidak setuju" pada pernyataan negatif, 
2) skor 3 mewakili pilihan "setuju" pada pernyataan positif atau pilihan "tidak setuju" pada pernyataan negatif,

3) skor 2 mewakili pilihan "tidak setuju" pada pernyataan positif atau pilihan "setuju" pada pernyataan negatif, dan

4) skor 1 mewakili pilihan "sangat tidak setuju" pada pernyataan positif atau pilihan "setuju" pada pernyataan negatif. Rumus yang digunakan untuk menghitung persentase dari masingmasing aspek adalah sebagai berikut.

$$
N P=\frac{A}{B} \times 100 \%
$$

Keterangan :

$$
\begin{aligned}
N P & =\text { nilai persen yang dicari } \\
A & =\text { proporsi total opsi yang } \\
& \text { dipilih oleh siswa } \\
B \quad= & \text { jumlah siswa }
\end{aligned}
$$

Hasil data respon ditelaah apabila besarnya percentage of agreement $\geq 61 \%$ maka modul digital fisika dapat dikategorikan positif (Masruroh \& Listiadi, 2015: 3). Produk akhir pengembangan ini berupa modul digital fisika interaktif pokok bahasan hukum newton tentang gravitasi yang telah diuji coba lapangan skala besar dan telah direvisi berdasarkan masukan validator ahli. Arikunto (2010) memaparkan bahwa kriteria respon siswa menurut nilai presentase ditunjukkan pada Tabel 1 sebagai berikut.

Tabel 1. Kriteria Respon Siswa

\begin{tabular}{ll}
\hline Interval Respon Siswa & Kriteria \\
\hline $80 \% \leq \mathrm{Na}<100 \%$ & Sangat Positif \\
$60 \% \leq \mathrm{Na}<80 \%$ & Positif \\
$40 \% \leq \mathrm{Na}<60 \%$ & Cukup Positif \\
$20 \% \leq \mathrm{Na}<40 \%$ & Kurang Positif \\
$\mathrm{Na}<20 \%$ & Sangat Kurang \\
& Positif \\
\hline
\end{tabular}

\section{HASIL DAN PEMBAHASAN}

Respon siswa diberikan melalui
angket setelah melakukan proses

pembelajaran menggunakan modul fisika digital. (Wati et al., 2017) memaparkan bahwa untuk menilai praktis atau tidaknya modul yang dikembangkan, dapat diukur berdasarkan penilaian dari angket respon siswa yang disebar pada saat pembelajaran dengan modul selesai. Modul fisika digital interaktif berbasis Articulate Storyline 3 pokok bahasan hukum newton tentang gravitasi diketahui tingkat kepraktisannya melalui hasil analisis dari respon yang diberikan oleh siswa setelah menggunakan modul tersebut dalam pembelajaran.

Hasil uji coba kecil, hasil respon siswa dalam mengikuti pembelajaran menggunakan modul dapat dilihat pada

\begin{tabular}{|c|c|c|c|}
\hline No. & Aspek & $\begin{array}{c}\text { Percentage } \\
\text { of } \\
\text { Agreement }\end{array}$ & Kriteria \\
\hline 1. & $\begin{array}{l}\text { Penyajian } \\
\text { Modul }\end{array}$ & $80,21 \%$ & $\begin{array}{l}\text { Sangat } \\
\text { Positif }\end{array}$ \\
\hline 2. & Kejelasan Isi & $72,92 \%$ & Positif \\
\hline 3. & $\begin{array}{l}\text { Ketercapaian } \\
\text { Tujuan }\end{array}$ & $91,67 \%$ & $\begin{array}{l}\text { Sangat } \\
\text { Positif }\end{array}$ \\
\hline \multicolumn{2}{|c|}{ Rata-rata } & $81,60 \%$ & $\begin{array}{l}\text { Sangat } \\
\text { Positif }\end{array}$ \\
\hline
\end{tabular}
Tabel 2 tentang hasil respon pada siswa berikut ini.

Tabel 2. Hasil Respon Siswa pada Uji Coba Skala Kecil

Data hasil analisis penilaian siswa pada uji coba skala kecil terhadap pernyataan respon siswa secara keseluruhan diperoleh yakni pada penyajian modul memperoleh skor ratarata sebesar $80,21 \%$, kejelasan isi memperoleh skor rata-rata sebesar $72,92 \%$, dan ketercapaian tujuan memperoleh skor rata-rata sebesar 91,67. Berdasarkan Tabel 2. tentang hasil rekapitulasi respon siswa pada uji coba skala kecil diketahui bahwa rata-rata penilaian respon siswa terhadap modul 
fisika digital berbasis Articulate Storyline 3 sebesar $81,60 \%$ dengan kriteria sangat positif. Data respon siswa uji coba skala besar pada tiap aspek ditunjukkan pada Tabel 3. berikut ini

Tabel 3. Data Hasil Respon Siswa Uji Coba Skala Besar

\begin{tabular}{|c|c|c|c|}
\hline No. & $\begin{array}{l}\text { Aspek yang } \\
\text { dinilai }\end{array}$ & $\begin{array}{c}\text { Percentage } \\
\text { of } \\
\text { Agreement }\end{array}$ & Kategori \\
\hline 1. & $\begin{array}{l}\text { Penyajian } \\
\text { Modul }\end{array}$ & $77,96 \%$ & Positif \\
\hline 2. & Kejelasan Isi & $87,50 \%$ & $\begin{array}{l}\text { Sangat } \\
\text { Positif }\end{array}$ \\
\hline 3. & $\begin{array}{l}\text { Ketercapaian } \\
\text { Tujuan }\end{array}$ & $86,11 \%$ & $\begin{array}{l}\text { Sangat } \\
\text { Positif }\end{array}$ \\
\hline \multicolumn{2}{|c|}{ Rata-rata } & $83,86 \%$ & $\begin{array}{l}\text { Sangat } \\
\text { Positif }\end{array}$ \\
\hline
\end{tabular}

Berdasarkan hasil uji coba skala besar, dapat diketahui bahwa aspek kejelasan isi modul fisika digital memperoleh skor rata-rata sebesar $87,50 \%$ dari yang sebelumnya pada uji coba skala skala kecil yaitu sebesar 72,92\%. Aspek penyajian modul memperoleh rata-rata sebesar $77,96 \%$ dan aspek ketercapaian tujuan memperoleh rata-rata sebesar $86,11 \%$. Rata-rata penilaian respon siswa terhadap modul fisika digital berbasis Articulate Storyline 3 pada uji coba skala besar mengalami peningkatan sebesar 2,26\% dari uji coba skala kecil.

Berdasarkan Tabel 3. tentang rekapitulasi respon siswa pada uji coba skala besar diketahui bahwa rata-rata penilaian respon siswa terhadap modul fisika digital berbasis Articulate Storyline 3 sebesar $83,86 \%$ dengan kriteria sangat positif. Apabila merujuk pada Tabel 1. tentang kriteria respon siswa, Arikunto (2010) memaparkan bahwa jika perolehan hasil respon siswa besarnya percentage of agreement $61 \%$ maka modul fisika digital interaktif berbasis Articulate Storyline 3 pokok bahasan hukum newton tentang gravitasi dapat dikategorikan positif dengan keputusan praktis dan layak digunakan.

Respon positif yang diberikan oleh siswa dikarenakan pembelajaran dengan modul fisika yang bersifat digital dan interaktif di kelas tersebut merupakan hal yang baru dan menjadikan siswa lebih tertarik untuk mempelajari fisika. Selain itu, adanya tambahan wawasan berupa kaitan antara materi hukum newton tentang gravitasi dengan salah satu kebudayaan yang terdapat di Kabupaten Jember menjadi nilai lebih bagi modul yang dikembangkan oleh peneliti karena materi yang disajikan sesuai dengan kejadian yang ada di sekitar peserta didik, sehingga modul fisika digital tersebut dapat mendorong keinginan siswa untuk mempelajari fisika. Hal ini sejalan dengan penelitian yang dilakukan oleh (Oktaviana et al., 2017) bahwa modul fisika yang berbasis kearifan lokal mendapatkan respon positif dari siswa karena memberikan informasi serta menanamkan karakter positif yang dimiliki oleh suatu daerah yang turuntemurun. (Sari et al., 2016) memaparkan bahwa modul pembelajaran yang mengintegrasikan sains, lingkungan, teknologi, dan masyarakat (salingtemas) mendapatkan respon yang positif dari siswa karena memberikan pengalaman belajar yang menarik dan menyenangkan bagi siswa.

Respon positif yang diberikan oleh siswa salah satunya dikarenakan modul yang dikembangkan bersifat menarik dan interaktif. Hal ini sejalan dengan penelitian yang telah dilakukan oleh (Nuraini \& Supriadi, 2018) yang mendapatkan hasil penelitian bahwa relevansi ketertarikan memperoleh respon tertinggi dikarenakan multimedia yang dikembangkan mampu menarik minat belajar fisika mahasiswa. Selain itu, yang menjadikan modul modul digital fisika ini menarik dan praktis adalah adanya evaluasi yang terdapat di dalam 
modul tersebut. Evaluasi yang menjadi bagian dari konten yang terdapat di dalam modul tersebut menjadikan siswa lebih mudah untuk mengukur tingkat pemahaman mereka serta lebih praktis jika dibandingkan dengan ujian yang bersifat tertulis. Hal ini sejalan dengan penelitian yang dilakukan oleh (Anggraeni \& Nuraini, 2020) yang menyatakan bahwa sistem ujian yang menggunakan computer based test mendapatkan respon yang sangat positif mulai dari kepraktisan, kemudahan, serta lebih menarik jika dibandingkan paper based test. Berdasarkan hasil analisis penelitian tersebut, maka dapat disimpulkan bahwa modul digital fisika berbasis Articulate Storyline 3 mendapatkan respon positif sebagai media yang praktis untuk menunjang proses pembelajaran fisika.

\section{SIMPULAN DAN SARAN}

Modul fisika digital interaktif berbasis Articulate Storyline 3 pokok bahasan hukum newton tentang gravitasi di SMA Plus AlAzhar Jember mendapat skor rata-rata respon siswa sebesar 81,60 \% dengan kriteria sangat positif pada uji coba skala kecil dan memperoleh prosentase sebesar $83,86 \%$ dengan kriteria sangat positif pada pada uji coba skala besar. Oleh karena itu, modul yang dikembangkan dikatakan menarik, praktis dan mudah untuk digunakan. Adapun saran untuk modul digital ini adalah perlu adanya pengembangan modul digital fisika agar dapat digunakan melalui website lain seperti browser, mozilla firefox, maupun website yang lainnya sekaligus untuk penambahan materi fisika yang lebih luas.

\section{DAFTAR PUSTAKA}

Anggraeni, F. K. A., \& Nuraini, L. 2020. Analisis Respon Mahasiswa Pendidikan Fisika Terhadap Computer Based Testing Pada Mata
Kuliah Manajemen Lab. Jurnal Pembelajaran Fisika, 9(3), 101.

Arikunto. 2010. Prosedur Penelitian. Jakarta: Rineka Cipta.

Atsani, L. G. M. Z. 2020. Transformasi Media Pembelajaran Pada Masa Pandemi Covid-19. Al-Hikmah: Jurnal Studi Islam, 1(1), 65-70. Retrieved from http://journal.unj.ac.id/unj/index.php/j tp

Jamun, Y. M. 2018. Dampak Teknologi Terhadap Pendidikan. Jurnal Pendidikan dan Kebudayaan Missio, 10(1), 48-52.

Masruroh, F., \& Listiadi, A. 2015. Pengembangan modul akuntansi piutang berbasis scientific approach pada mata pelajaran akuntansi keuangan. Jurnal Mahasiswa Teknologi Pendidikan, 3(2), 1-6.

Mastuti, E. 2016. Pemanfaatan Teknologi Dalam Menyusun Evaluasi Hasil Belajar:Kelebihan Dan Kelemahan "Tes Online" Untuk Mengukur Hasil Belajar Mahasiswa. Jurnal Penelitian Psikologi, 7(1), 10-19.

Mikrajuddin, A. 2017. Fisika Dasar II. Bandung: Institut Teknologi Bandung.

Mulyadi, M. 2011. Penelitian Kuantitatif Dan Kualitatif Serta Pemikiran Dasar Menggabungkannya. Jurnal Studi Komunikasi dan Media, 15(1), 128.

Nugraha, D. A., Binadja, A., \& Supartono. 2013. Pengembangan Bahan Ajar Reaksi Redoks Bervisi Sets, Berorientasi Konstruktivistik. Journal of Innovative Science Education, 2(1).

Nuraini, L., \& Supriadi, B. 2018. Analisis Pemanfaatan Multimedia Terhadap Penguasaan Konsep Reaksi Nuklir Mahasiswa pada Mata Kuliah Fisika Inti. Saintifika, 20(2): 22-31.

Oktaviana, D., Hartini, S., \& Misbah, M. 2017. Pengembangan Modul Fisika Berintegrasi Kearifan Lokal Membuat 
Minyak Lala Untuk Melatih Karakter Sanggam. Berkala Ilmiah Pendidikan Fisika, 5(3), 272.

Prasetya, T. I. 2012. Meningkatkan Keterampilan Menyusun Instrumen Hasil Belajar Berbasis Modul Interaktif Bagi Guru-Guru Ipa Smp N Kota Magelang. Journal of Educational Research and Evaluation, 1(2), 106-112.

Purnama, S., \& Asto B, I. G. P. 2014. Pengembangan Media Pembelajaran Interaktif Menggunakan Software Articulate Storyline Pada Mata Pelajaran Teknik Elektronika Dasar Kelas X TEI 1 Di SMK Negeri 2 Probolinggo. Jurnal Pendidikan Teknik Elektro, 3(2), 275-279.

Sadiman, A. S., 2007. Media Pendidikan: Pengertian, Pengembangan, dan Pemanfaatannya. Jakarta: PT Raja Grafindo Persada.

Sari, D., Wahyuni, S., \& Supriyadi, B. 2016. Pengembangan Modul Pembelajaran Ipa Berbasis Salingtemas (Sains, Lingkungan, Teknologi, Masyarakat) Di Smp. Jurnal Pembelajaran Fisika Universitas Jember, 5(3), 218-225.

Sulardi, S., Nur, M., \& Widodo, W. 2017. Pengembangan Perangkat Pembelajaran Fisika Model Problem Based Learning ( $\mathrm{Pbl}$ ) Untuk Melatih Keterampilan Berpikir Kritis Siswa. JPPS (Jurnal Penelitian Pendidikan Sains), 5(1), 802.

Wati, M., Misbah, Ramadhaniah, N. E., \& Mahtari, S. 2017. Pengembangan Modul Fisika pada Pokok Bahasan Fluida Statik dengan Menggunakan Model Pembelajaran Sains Teknologi Masyarakat (STM) di SMAN 4 Banjarmasin. Inovasi Penelitian dan Pembelajaran IPA Berwawasan Konservasi (pp. 117-123). 